\title{
Interest and the Modern Economy
}

\section{Arshad Zaman \& Asad Zaman*}

\section{Introduction}

Can the modern economy function without a market for interestbased credit? This question has acquired some urgency in the wake of the recent Shariat Court ruling banning interest in Pakistan. Some pundits have pronounced that great harm will result from the banning of interest ${ }^{1}$. Actually, such pronouncements are based on a lack of understanding of both the modern economic system, as well as the nature of the Islamic prohibition of interest. As we hope to demonstrate clearly below, the modern economy can function very well, indeed better in some ways ${ }^{2}$, with a prohibition on interest rate payments of the Islamic type.

\section{Some Common Misunderstandings}

Many people believe that modern economics demands that there should be no restrictions on the functioning of markets. Clearly, this is not the case. Every society, in accordance with its values, imposes restrictions on the functioning of certain markets. Thus we do not allow markets to function in illicit drugs, gambling, prostitution, slavery, etc. Moreover, even though we know that illegal markets do function in these goods and services, no one advocates that just because markets exist they should be allowed to exist. Until quite recently, in conformity with Christian teachings against usury, Christian-modern societies did not allow markets for interestbased credit. It is only with the progressive crisis of faith in Christianity that

\footnotetext{
* The authors are Managing Director, Arshad Zaman Associates (Pvt.) Ltd., Economic \& Financial Consultants based in Karachi and Professor at the Lahore University of Management Sciences, respectively.

${ }^{1}$ For example, $\mathrm{H}$. Alavi writes that the ban on interest rate is a " threat to the stability and viability of the Pakistan economy," in an article in Dawn on 9 Feb 2000. Unfortunately, instead of providing the economic basis for his statement, Alavi writes mainly about principles by which the Quran should be interpreted, stepping far outside his own field of specialisation.

${ }^{2}$ For example, M Khan (1986) has shown that interest based credit increases the risk of banking crises. Our results below support this conclusion, though the mechanism producing crises is different in our paper. Also, Presley and Sessions (1994) have shown that mudarabah financing enhances capital investment because of its efficiency as a revelation device, relative to conventional interest based finance.
} 
such markets have come to be permitted, and are now seen to be normal. ${ }^{3}$ Muslims have not suffered any such crisis of faith, and continue to view these markets as morally reprehensible. It is therefore entirely "modern" for Muslim societies to have laws that reflect their values.

A major misunderstanding regarding the prohibition of interest is that such a law will make it impossible to earn a return on capital. As a consequence, investments will dry up and the growth of the economy will be reduced or eliminated. In fact, as we will show below, Islamic law provides for a number of permissible alternatives to interest, and hence allows for earning a return on capital. The economic function which the interest rate performs can be fulfilled without using the particular form which it takes in modern banking. This may seem surprising since the opposite is frequently asserted in the popular press, but this point is well understood by economists. For example, one of the current leading texts in macroeconomics, Obstfeld and Rogoff (1996), states that in the presence of profit-sharing or other arrangements, 'the ban on ... interest ... would not interfere with the efficiency of the economy'.

There is no reason to suppose that investment will decline under a switch to the Islamic system. Implementation of the Islamic Law would eliminate returns on risk-insulated fixed returns (on credit), it brings into existence other types of return not only on entrepreneurial capital but on permissible credit-like transactions. For example, Islamic law permits profits on the purchase and re-sale of goods with a mark-up (murababa), which banks can use to fulfill the businessman's need for credit to finance the purchase of assets. This is a very common mode of financing in the Islamic banks and financial organisations that have been created. This method is virtually risk free and creates an instrument for credit very much like conventional interest-based loans. At the other end of the spectrum, we have Islamically permissible common stocks, which have high returns and high risks. ${ }^{4}$ What is relevant here is that while the mix of financial instruments available would change in an Islamic system, they would not differ much in functionality from the mix currently available in a modern economy.

\footnotetext{
${ }^{3}$ Even so, until recently the majority view has been that governments should intervene to keep these rates low. It is only in the last 30 years or so that this majority view has been assailed. Here too, with the financial crises of the last two decades (and more), a significant backlash is building up.

${ }^{4}$ For a thorough discussion of the range of Islamically permissible instruments and also a justification of why certain types of transactions are permitted while others are not, see Usmani (1998). Also, as shown by Khan and Mirakhor (1989), the IS-LM framework for macroeconomic analysis would work almost exactly as it does in a conventional economy.
} 
A third misunderstanding concerns the critical role of credit in the nature of modern investment and business spending. Contrary to popular misconception, the majority of funds which finance business needs in the USA, for example, is raised as equity (and not loans) on the open market (that is, common stocks, which are perfectly permissible under Islamic Law). Kester (1986) lists debt-to-equity ratio for major categories of business in USA and Japan, and shows that most of these ratios are substantially below unity, so that (Islamically permissible) equity financing is much more prevalent than (interest-based and prohibited) debt financing. This amount of debt would be reduced even further were it not for the artificial tax advantage of debt-based financing in these countries (since interest payments can be written off). As a practical matter, equity financing is widely used and has many advantages over debt-based financing, listed in many texts on corporate finance $\longrightarrow$ see for example, Ross, et. al. (1995). These advantages are also discussed in a later section of this paper.

A fourth misunderstanding relates to the critical role of bank credit in supporting the prosperity of Pakistan. We must realise that while Pakistan is a new state, it is one of the oldest economies in the world; pre-dated only by modern Iraq and Egypt. For several thousand years of its existence, interest-based credit has been against the law in Pakistan. It is only in the last 50 years that interest-based bank credit was introduced in the economy, and its consequences are the stuff of current newpaper headlines. While there are complex reasons that account for the present crisis in banking (and non-bank financial intermediaries), no one can deny that a link between bank credit and the returns on the commercial undertaking that it financed would have been a good thing.

Finally, the degree of change required is commonly over-estimated. In fact, during the process of Islamisation under the Zia regime, banks have already rewritten their lending procedures to come into apparent conformity with Islamic Law. Thus, in principle, interest-based transactions have been replaced by those based on murabaha (markups and transactions costs), leasing, and some musharaka, all of which are permissible under Islamic Law. Appearances are deceiving, however, and only the form of the transactions have changed, with no change in the underlying transaction.

Unfortunately, for inexplicable reasons, foreign transactions have been effectively excluded from the Shariat Court ruling. Since the government is the largest player in the market for credit, and interest-based foreign borrowing is its mainstay, as a practical matter, there is unlikely to be any change in the banking system already prevailing in Pakistan. Changes will occur only if there is an attempt to bring about real change in the form of the underlying transaction rather than the nomenclature being used to 
describe the transaction. Finally, it is unclear whether the executive body of the government will move to implement the Shariat Court ruling in detail, or whether they will be satisfied with the nominal implementation that is already in existence.

The present paper is concerned with the issues that will arise if Pakistan moves towards a genuinely Islamic system, as opposed to one which is Islamic in name and appearance only.

\section{Debt Versus Equity Financing for Business Needs}

Although there are many details, at a broad level we can categorise business needs for funds into two categories: working capital and investment. Working capital is needed for example when a business buys goods, often on credit, with the expectation of getting money from selling them. When credit from the original seller is not available, short term interest based loans are frequently used for financing the holding of inventory. The Islamic alternative here is Murabaha. Instead of taking a loan from a bank to purchase goods, the bank purchases the goods and resells them to the business at a profit. This profit takes the place of interest. For longer term loans for investment purposes, the Islamic alternative to an interest-based loan is Musharka, where the bank becomes a silent partner in the enterprise. A share of profits replaces interest as the gain on capital. In both cases, abstracting from complexities, we can model the Islamic transaction as being equity based -- the return paid to the bank has some relation to the earnings generated by the business. The earnings of the business is a random variable (for inventories, because the timing of sales is random and hence the present discounted value of the resulting cash stream is random). In both Islamic instruments, some of this uncertainty is passed on to the lender. The alternative instrument is debt-financing, where the business must pay a fixed return regardless of its own performance. In this section we consider the question of financing business activities from the business point of view: Will businesses prefer debt financing to equity financing?

From a purely practical point of view, equity based finance is typically more common than interest-based finance in the US and Japan, as shown in Kester (1986). This shows that businesses tend to prefer equity based financing. This is in spite of the fact that debt based financing is advantageous due to tax laws in the US and Japan which permit businesses to write off interest expenses, but not dividend payments. Without this tax advantage, the proportion of equity financing would be even higher than it currently is. There seems no reason to suppose that completely eliminating interest based loans would cause any distress to businesses. 
From a purely theoretical point of view, we have the ModiglianiMiller Theorem $(1958,1964)$. According to this theorem, it is economically equivalent whether business financing is done using common stocks (which is the Islamically permissible form of financing) or bonds (which are interest bearing and hence banned). Thus, at least for the purposes of financing business activity, theory recognises no difficulties with switching to purely Islamic forms. Critics have argued that the M\&M Theorem fails to hold when real world complexities are taken into account. Taking these complexities into account actually favours equity based financing over debt based financing for many reasons (See Ross et. al. (1993) and Jensen \& Smith (1986) for a discussion). The fundamental issue which emerges is that the value of a firm is equivalent to its stream of incoming payments. All claims on the firm must be paid out of this stream. Equity based finance is co-ordinated with this stream, while debt based finance is externally prescribed. In bad times, interest payments must continue at the same rate, while equity based payments are reduced. Due to this, the probability of bankruptcy and financial distress are increased when debt based financing is used $^{5}$. Since this issue is critical to some of our arguments to follow, we spell it out further in the next paragraph.

Consider a situation where a business has a random stream of earnings. For simplicity, suppose that it will earn $\$ 1000$ with probability 90 per cent and $\$ 100$ with probability 10 per cent. Then the expected earnings are $\$ 910$ and so, on the average, an interest repayment of $\$ 200$ will be well within the capability of the business. However a fixed liability of $\$ 200$ will cause the business to go bankrupt (or go into financial distress) about 10 per cent of the time in this scenario. If this same $\$ 200$ is repaid as a 22 per cent share of returns, there will be on the average the same repayment to the lender ( $\$ 220$ in 90 per cent of the cases, and $\$ 22$ in 10 per cent, averaging out to $\$ 200$ ). However the probability of bankruptcy or financial distress is reduced to zero.

Other than tax advantages (which are artificial, in the sense that they merely re-distribute income and are not net gains to the economy), there is basically only one situation where businesses will prefer debt-based financing to equity based financing. That is when the public perception of

\footnotetext{
${ }^{5}$ On this, see also Mohsin Khan (198?): “...the Islamic system may well turn out to be better suited than the interest-based banking system to adjust to shocks that can lead to banking crises. In an equity-based system shocks to the asset positions of banks are immediately absorbed by changes in the nominal values of shares (deposits) held by the public in the banks. Therefore, the real values of assets and liabilities would be equal in all points of time. In the traditional banking system, since the nominal value of deposits is guaranteed, such shocks can cause a divergence between real assets and real liabilities, and it is not clear how this disequilibrium would be corrected...”
} 
their returns is lower than what the businessmen know it will be. In such a situation, the public/banks will demand a greater share in equity than the equivalent payment in debt. Instead of seeing this as a problem with equity financing, one could equally well view it as a problem of informational asymmetries. The problem could be resolved by sharing information in such a way that common perceptions emerge. It should also be possible to solve this problem using more complicated sharing rules instead of a flat percentage.

Overall, we can conclude that business will not be fundamentally affected by a complete ban on interest rates. On the whole, there will be favorable effects due to reductions in probabilities of financial distress and bankruptcy. These may be counterbalanced to some extent by problems arising due to informational asymmetries. These are small effects, and should not have much overall impact on the big picture.

\section{Effects of Transition to Islamic Law on Banks}

Naive faith in the workings of "the invisible hand" leads to the belief that whatever practices are in existence are necessarily optimal. The ease with which multiple equilibria arise in modern game-theoretic formulations has led economists to reconsider such comfortable assumptions. In models with mutiple equilibria, historical circumstances determine the one which is arrived at, and there is no guarantee that the best equilibrium will be selected. In addition, economics as a whole is well equipped to analyse marginal changes, but shifts from one equilibria to another bring into play big changes which we are ill equipped to analyse.

The mere fact that interest-based loans exist is not enough to show that their existence is necessarily an optimal way to organise business and banking. Since interest is banned in Judaism, Christianity and Islam, there have been many periods in history where interest has not been used. The illusion that current times are the best and most sophisticated has always been present throughout human history. This has led certain authors to suggest that in the 'primitive past' economic affairs were simpler and thus interest could be avoided. A serious study of history disabuses this naive idea -- historical studies show that sophisticated and complex business transactions were conducted in many periods of history, including the Khilafate Usmania, which had its own version of a global economy.

Current organisation of banks appears curiously inefficient from an economic point of view. We have large banks which make small (relative to the banks assets) loans to diverse businesses, each of which has random returns. If the bank accepts return based repayment (as in Islamic system), 
then, since the bank has a diversified portfolio, the laws of probability guarantee that its return will show much less variability than the returns of individual businesses. This will reduce the overall risks in the system, since the banks will absorb a portion of the risk of the individual investors. If instead the bank demands fixed repayment on loans, this will increase the risks faced by the individual investors (leading to higher probabilties of business failure and financial distress). Since the banks portfolio is large and diversified, it is more efficient for it to bear (smaller) risk; instead, the interest based system magnifies risk for the individual investors who are already more vulnerable. Given the apparently greater efficiency of the Islamic type system, why are banks not organised along these lines? One answer could be that historically banks have offered fixed interest rates to depositors, creating a fixed set of liabilities. It is easy to construct formal models where banks, having a fixed stream of liabilities, would require fixed stream of payments from borrowers to be able to meet their liabilities, and would be hurt by a transition to the Islamic system. However, for the system as a whole, it would be optimal to make a transition to the Islamic system where banks would obtain profits which are based on business outcomes and would also pay depositors a random, return-based amount. There is a tradeoff made in this transition: the risks to businesses are passed on, in a much attentuated form due to diversification, to the consumers, who will now have random returns on their deposits. We will return to a more detailed discussion evaluating the costs and benefits later in this article.

\section{Effects of Interest Ban on Consumers}

As just discussed, the consumers would face a more variable stream of returns on deposits. There would be compensation in the form of reduced risk of bank failures, as we will show later on. In an Islamic society, practicing Muslims would face no loss from this transition as the consumers would prefer a variable rate of return. Their option is to keep money out of banks which leads to zero returns, or invest it directly, which consumers are ill-equipped to do. Serious Muslim investors do obey the law, thus depriving the economy of money which may be useful in increasing investment and hence the growth of the economy. Thus there is a distinct possibility of growth in available funds for investment following a move to Islamise the banking system. Even Europeans have become aware of the vast potential of attracting the funds of Muslim investors, and are creating instruments to tap into this fund. The Islamic Dow-Jones average and FTSE index, as well as several funds which invest in only Islamically permissible instruments have recently been created. This leads to the possibility that the creation of a truly Islamic banking system may actually attract foreign investment from 
Islamically minded investors, instead of reducing it, as has been suggested by several opposed to the move.

Another issue of importance to consumers is the financing of loans for consumer purchases, such as houses and cars. These can easily be handled via the instrument of Murabaha, where the bank purchases the item, and resells it to the consumer on installments for a profit. Muslim groups have already implemented schemes of this kind in the USA and Canada, showing their feasibility. See website www.lariba.com for one such group, legal and economic feasibility studies, and other relevant statistics. If the transaction runs smoothly to completion, there are virtually no differences between it and the conventional interest based financing (other than the artificial tax advantage of the interest based loan). In case of default, the Islamic method appears superior. It would save the banks some portion of the legal costs currently spent on repossession from recalcitrant consumers and resale, since they would have title to the assets.

\section{Effects of Interest Ban on Government Finances}

Unlike businesses, governments finance a wide range of activities (education, infrastructure, public goods, military) which are not directly renumerative. Thus it would be difficult for them to take loans which would be financed out of future revenues. Can governments function if they are denied access to interest based loans, currently widely used by all governments all over the world?

Contrary to what may be supposed, David Ricardo showed that the government can always replace financing via debt by financing via taxation (or vice-versa). This proposition has come to be known as the Ricardian Equivalence Theorem. For our purposes here, more important than the debate over the validity or failure of Ricardian Equivalence in practice $^{6}$ is that it expresses a fundamental and important insight: Government borrowing must sooner or later be repaid by taxes, since this is the only source of government revenues. Under perfect foresight, infinitely long living consumers are indifferent between government financing from taxes and that from loans, since they realise that eventually they will repay the loans in the form of higher taxes. Failure of Ricardian equivalence results from the short horizons of consumers, and lack of equality of discount rates applied, among other possibilities.

\footnotetext{
${ }^{6}$ See Han-Yung Jung's (1994) Ph.D. Thesis for an empirical evaluation and references to the literature.
} 
We do not mean to suggest that governments should replace borrowing by taxation; this is not politically feasible. What is important to realise is that borrowing is not a new and different instrument for financing; it is fundamentally a method for pushing taxation forward onto later times. Governments are happy to do this, since they can borrow and later the government will be saddled with the debt. Consumers are also willing to do this since they discount payments by future generations. Thus there is a large measure of lack of responsibility and foresight, as well as long range planning, which encourages the government tendency to finance via debt rather than taxation. This shows that banning of interest based debt will encourage responsible government, by not giving them the option of saddling future governments and unborn generations with debt. This by itself may well be of great value and welfare increasing. As documented by Ferraro and Rosser (1994) the Third World currently owes more than 1.5 trillion dollars to the First World and the annual net flow from the poor countries to the rich countries has been over 50 billion dollars in the past decade ${ }^{7}$.

The conventional view is that the government borrows for the development of projects which enhance productivity. The increased revenues from the additional productivity would be used to pay back the loans without imposing any debt burden on future generations. If the conventional view is true, then borrowing to repay interest on previous loans should be very rare or nonexistent. In practice, a large number of new loans go towards financing interest payments on previous debts, showing that sufficient additional productive capacity was not generated due to the earlier loan. The evidence supports the alternative view that corrupt governments borrow for private benefits. In this case, later generations and governments are saddled with a debt burden without any compensating benefit in the form of productivity gains due to improved infrastructure. A ban on interest protects future generation from the corruption of earlier governments by denying these governments the possibility of taxing later generations by creating debt. This is clearly of great benefit in a country such as Pakistan, where no one denies the deep corruption in government. However such a ban may also have the effect of preventing productive investments by the government, which may not be able to finance them. Thus we need to find a way to allow the government to finance genuinely valuable and productive projects, without allowing them to borrow in an

\footnotetext{
${ }^{7}$ Each year seventeen million children die from the combined effects of poor nutrition, diarrhea, malaria, pneumonia, measles, whooping cough, and tetanus, diseases that are rarely fatal in the developed countries. One in twenty of these impoverished children dies before reaching the age of five. A large proportion of these deaths is attributable to the burden of debt repayment faced by the poorer countries.
} 
indiscriminate fashion. Islamic law and heritage does allow a number of options, all of which can accomplish this goal of discrimination. It is important to note that the government and the powerful elite would be expected to resist these alternatives since a responsible government would take away the easy opportunties for windfall profits enjoyed by those with easy access to loans which need not be repaid by individuals but will be paid by the public in the future.

Islamically permissible ways of financing projects without taking interest based loans depend on the nature of the project. For revenue generating projects such as power generating dams, it would be best to finance out of the revenues of the project. If the project revenues are insufficient, this a clear indication of the economic nonviability of the project. Projects such as highways and bridges could, in principle, be financed from tolls to be paid. Such forms of finance may prove insufficient for various reasons. In these cases, the beneficiaries from the projects should be taxed. Roads increase land values, and the owners should be taxed. Similarly beneficiaries from other development projects should be made to contribute to the projects. There is an example of Khalifa Umar in which he asked everyone to put in a day of work in building a road. Creative financing like this will reduce corruption, get the people involved in the development project, overcome resistance to government revenue collection since the benefits will be directly visible, and encourage greater participation in the government. Certain projects, such as educating the poor, cannot be paid for either out of revenues generated out of the project or by the target population (since it is too poor, and the benefits too diffuse and long range). In such cases, the Zakat fund can be employed and also appeal to public donors may be made. The tremendous success of public charities such as Edhi trust shows that there is no lack of willingness of the public to participate in good projects. Resistance to paying taxes and supporting government projects arises solely from well-founded suspicions of corruption in the government. To the extent that banning interest will force the government to reduce corruption in order to be able to win the confidence of the public and attract funding for its projects, this will be a change all to the good.

Another important beneficial effect of preventing the government from taking interest based loans will be the freeing of capital for domestic investment. It has been widely observed that when the government issues bonds paying high real interest rates, the public invests in them in preference to productive interest. Peter Farkas (1998), mentions that one of the reasons for the collapse of Russian industry is that the lucrative returns available on financial markets led to reduction of capital available for productive investments. In this connection, Mehra and Prescott (1985) have 
shown that the U.S. treasury bills in the last century have payed a real interest rate of around less than 1 per cent. This 1 per cent could be regarded as compensation for inflation risk. This leads to the possibility that a genuine risk free government bond could be financed at zero per cent interest rate in real terms. A credible and honest government should be able to obtain financing for its legitimate projects by issuing Islamically permissible indexed bonds at zero per cent interest. Such a policy would also not compete with private sector needs for financing productive investments.

\section{Some General Effects of the Prohibition of Interest}

We have considered the effects of banning interest based loans on consumers, banks, business, and government, separately. In this section we consider some global effects which could be expected from the Islamic law. Several socially beneficial effects would result from such a ban.

Financing for superior investment projects: Since banks are effectively insulated from the outcomes of business in the system of interest based loans, they lend on criteria different from the intrinsic merit of the investment. Potentially very good investments would be passed up if the investor does not have enough collateral to guarantee repayment in case of an unfavourable outcome. If return to banks is based on investment outcome, as under Islamic law, we may expect that the mix of investment projects financed would shift towards the more profitable and hence the economically more valuable projects. As a practical matter, the rate of failure of new business startups in the USA is close to 70 per cent. This high rate is partly due to the fact that banks are willing to finance poor projects if they have sufficient collateral to ensure that they will be repaid. Such a high rate of failure inflicts large deadweight losses on society. It seems likely that if banks take greater interest in outcomes, these losses can be reduced.

Better utilisation of information: Since banks finance many projects, they have potentially valuable information to share with investors. A typical new business startup may be a first or second effort, whereas the bank is likely to have made loans to several similar businesses. Under conventional interest-based financing backed up with collateral, the bank has no real incentive to share its information -- it is guaranteed a fixed return in any case. In the Islamic system, the return to the bank depends on the return to the investor and hence the bank will have a great incentive to ensure that the new investor has the best possible information for planning. Realising that small investors have relatively poor information available, many government agencies have tried to fill the vacuum and provide 
relevant information. However a financially interested party would obviously do a better job of providing this service.

More opportunities for the poor and better income distribution: The current collateral based system for financing business effectively locks the poor out of participation in the economic activities of the nation as a whole. Schemes like ROSCA (committees in local terminology) show creative efforts to get access to finance by those who are ineligible to borrow from banks by conventional criteria. Banning interest should have the effect of allowing for greater access by the population to finance, and hence lead to a better income distribution.

Maintenance of Independence and Sovereignty: The use of debt as a tool for control is ancient. Blaisdell (1929) shows how the Ottoman Empire was subjected to European influence by the use of debt. In modern times, the IMF and WB interfere with sovereignty on all fronts. Substantial pressure can be brought to bear on indebted countries to formulate policies contrary to the national interest. It is no longer denied even by the WB that its policies have generally caused much harm to the poor. Motivated mainly by ensuring repayments, IMF structural adjustment programmes have generally been harmful to nations which have adopted them. It is quite interesting to note that nearly all the IMF/WB debt has been contracted by interim governments in Pakistan, which were not responsible to the people, and did not look forward to future repayment. Representative governments as well as responsible military leaders have generally avoided binding the country to debts which would adversely affect the future.

Avoidance of Debt Crises: As we have argued, interest-based loans lead to irresponsible borrowing and lending. This in turn leads to banking crises from time to time as fixed obligations cannot be met from a payment stream which is random and variable. Such crises inflict tremendous hardships and costs on all segments of society, but most of all on the poor. For example, Ferraro and Rosser (1995) details the current debt crisis facing the world and the hardships inflicted on many parties by this crisis. If the world as a whole moves towards an non-interest based system, it seems likely that such crises could be avoided.

Justice: As Tawney (1926) and others have noted, the divorce between issues of morality, ethics and justice on the one hand and material affairs, economics and business on the other hand, was effected over the period of sixteenth and seventeenth century in Europe. Things have proceeded so far that Milton Friedman (1997) feels no discomfort in arguing that 'Profits should be the only business of business,' even if these profits 
lead to deaths ${ }^{8}$. Thus it sounds strange to modern ears to bring up issues of ethics and justice, on the basis of which interest has been banned for such a long period in the common heritage of mankind. The issue is that reward should only be given for productive behaviour. It is on this principle that lotteries and gambling are banned in Islam, since the winners gain without having done anything productive. Similarly the mere ownership of capital is not considered a productive act (much as capitalists may wish to convince us otherwise). It is to counter these ethical considerations that justifications were offered for interest in terms of the 'rewards for waiting' etc. in early European debates on the issue. As a silent partner in a business enterprise, a capitalist is entitled to reward for the risk he takes. The risk-free reward embodied in interest is not just, since the capitalist gets it without doing anything productive -- mere ownership not being considered a productive activity.

\section{Conclusions}

We have made a detailed examination of the institution of interest and shown that prohibiting it would not lead to discernible difficulties for modern institutions. In many different ways, the resulting changes would be beneficial as a whole to society. The question that naturally arises in the mind of a skeptic would be that if the interest-based system is so inefficient, why has it continued for so long?

As far as the private sector is concerned, in the USA and Japan, it seems likely that businesses would finance close to 100 per cent of their needs by equity based methods if it were not for the tax advantage of interest based loans. Thus a law favouring interest based financing is responsible for the persistence of interest. In the public sector we have listed many reasons why irresponsible governments and corrupt politicians would favour the use of interest based loans over alternative Islamically viable instruments. The fact that debt allows manipulation of the other party creates an incentive for the powerful to use interest based debt as a tool. When the powerful of the world have reasons to prefer interest based loans, we need look no further for a reason for its prevalence.

\footnotetext{
${ }^{8}$ See Friedman vs. Alameda (1997). Alameda discusses a case in which Chevrolet decided to manufacture defective Pintos knowing it would lead to about 700 deaths on the basis of profit loss considerations showing that an immediate recall and correction of defect would be more expensive than the eventual liability suits resulting from the deaths. Friedman counters by saying that all moral judgements are relative and subjective and hence businesses should not get involved in making moral decisions, but just pursue profits.
} 
126 The Lahore Journal of Economics, Vol.6, No.1

\section{References}

Alameda, 1997 'are Profits the only business of business? NO," in Taking Sides: Clashing Views on Controversial Issues, 8th edition, edited by T.R.Swartz and F.J. Bonello, McGraw-Hill, NY.

Peter Farkas, 'The Collapse of Russian Industry", Working Paper \# 97 of the Institute for World Economics, Hungarian Academy of Sciences. H1124 Budapest, Kallo Esperes U. 15. Dec. 1998.

Vincent Ferraro and Melissa Rosser, 1994 'Global Debt and Third World Development", in World Security: Challenges for a New Century, edited by Michael Klare and Daniel Thomas, St. Martin's Press, New York, pp. 332-355.

Milton Friedman, 1997 "Are Profits the only business of business? YES," in Taking Sides: Clashing Views on Controversial Issues, 8th edition, edited by T.R.Swartz and F.J. Bonello, McGraw-Hill, NY.

Jensen and C. Smith, 1989 The Modern Theory of Corporate Finance, McGraw Hill, NY 1989.

Jung, Han-Yung, Bayesian Tests of the Ricardian Equivalence Proposition, Ph.D. Thesis, Johns Hopkins University, 1994. UMI number 941994.

Kester, "Capital and ownership structure: a comparison of US and Japanese manufacturing corporations,” Financial Management 15 (Spring 1986).

Mehra and Prescott, "The interest premium puzzle”, Journal of Monetary Economics, 1985.

Mohsin Khan, Islamic Interest Free Banking: A Theoretical Analysis, IMF Staff Papers (33) 1/1, March 1986, pages 1-27.

Mohsin Khan and Abbas Mirakhor, The Financial System and Monetary Policy in an Islamic Economy, Journal of the King Abdulaziz University, 1, 1989, pages 39-58.

F. Modigliani and M. H. Miller, "The Cost of Capital, Corporate Finance, and the Theory of Investment," American Economic Review 48, June 1958, pp.261-297. 
F. Modigliani and M. H. Miller , "Corporation Income Taxes and the Cost of Capital: A Correction,” American Economic Review 53, June 1963, pp. 433-43.

Maurice Obstfeld and Kenneth Rogoff, 1996, Foundations of International Macroeconomics, MIT Press, page 273 footnote 5.

Blaisde11, 1929, European Financial Control in the Ottoman Empire, Columbia University Press, New York.

Stephen Ross, Westerfield and Jordan, 1993, Fundamentals of Corporate Finance, Irwin, NY.

R. H. Tawney, 1926, Religion and the Rise of Capitalism, Harcourt, Brace, and Co., NY.

Muhammad Taqi Usmani, 1998, An Introduction to Islamic Finance, Idaratul Ma'arif, Karachi, Pakistan. 